\title{
単軸スクリュ押出機に扔ける熱可塑性 プラスチックの溶融の促進
}

\author{
中村和之*・酒井忠基*
}

\section{Melting Acceleration of Thermoplastic Materials in the Single Screw Extruder}

\author{
Kazuyuki Nakamura and Tadamoto SakaI
}

\begin{abstract}
In this report, the melting behavior of thermoplastic materials has been investigated, which is important in the analysis of the plasticating performance of single screw extruder with forced feeding section. Screw removal experiments were carried out to observe the melting process of polypropylene and polyethylene. Based on these experimental results, an improved melting mechanism was utilized to accelerate the melting rate in the screw channel. The rapid melting of the solid bed is accomplished by conduction heat, viscous dissipation in the melt film and solid circulations caused by drag force and high pressure gradients. This improved melting mechanism was observed experimentally in the newly developed screw channel, which was different from Tadmor's melting model.
\end{abstract}

Key words : Extrusion/Single screw/Forced feeding/Plasticating behavior/Thermoplastics/Melting

\section{1. まえがき}

近年, 単軸スクリュ押出しに対する低温, かつ高押 出し量の要望が高まるにつれて, これに対処するスク リュを設計するためには，スクリュの溶融部における 溶融速度を考慮することが不可欠とな⿰てきている.

溶融に関しては，コンベンショナルスクリュを使っ ての Maddock ${ }^{11}$ のスクリュ引抜き実験から得られた 溶融モデルに基づいて Tadmor ${ }^{2)}$ が最初に溶融理論を 提案して以来, 飛躍的な進歩がなされてある程度理論 解析が可能となっている. しかし, 低温かつ高押出し 量を達成しようとすると, これらの溶融理論から明ら かなように，溶融不足によりその良質限界押出し量に は限界があった．そして単軸スクリュの溶融能力の飛 躍的な改善が望をれていた。

* (株) 日本製鋼所機械電子技術研究所 広島市安芸区船越南 1-6-1 ( 1989.2.8 受理
筆者らも, 熱可塑性プラスチックの押出しにおける 溶融過程のもつ役割に注目して,すでに単軸スクリニ の溶融, 混練過程の検討 ${ }^{31 ~ 7) ~}$ および二軸スクリュの溶 融, 混練過程の検討と溶融速度の推定方法について検 討を行ってきだ リュでは達成できなかった良質限界押出し量の飛躍的 な向上を目指して，単軸スクリこでの新しい機構によ る溶融の促進を図った. そして高能力単軸スクリュ押 出機を開発して実用に供している ${ }^{13)}$.

本報では, 単軸スクリ二押出機の可塑化押出し特性 を解明するうえで重要な溶融挙動について検討し, こ れらを積極的に利用して溶融の促進を図り, 良質限界 押出し量を飛躍的に向上した結果を報告する.

\section{2. 供試材料および実験装置}

\section{1 供試材料}

実験には代表的な熱可塑性プラスチックとしてポリ プロピレン（PP と略記）と, 直鎖状低密度ポリエチ 
Table 1 Physical properties of raw materials used

\begin{tabular}{llccc}
\hline & PP (1) & PP (2) & LLDPE (1) & LLDPE (2) \\
\hline Grade & NOBLEN & NOBLEN & ULTZEX & ULTZEX \\
Melt index* $(\mathrm{g} / 10 \mathrm{~min})$ & 2.26 & MA 8 & $2020 \mathrm{~L}$ & $3520 \mathrm{~L}$ \\
$\rho_{s}\left(\mathrm{~kg} / \mathrm{m}^{3}\right)$ & $9.00 \times 10^{2}$ & $9.00 \times 10^{2}$ & $9.20 \times 10^{2}$ & $9.35 \times 10^{2}$ \\
$\rho_{m}\left(\mathrm{~kg} / \mathrm{m}^{3}\right)$ & $7.60 \times 10^{2}$ & $7.60 \times 10^{2}$ & $7.80 \times 10^{2}$ & $7.80 \times 10^{2}$ \\
$C_{s}\left(\mathrm{~J} /\left(\mathrm{kg} \cdot{ }^{\circ} \mathrm{C}\right)\right)$ & $2.01 \times 10^{3}$ & $2.01 \times 10^{3}$ & $2.76 \times 10^{3}$ & $2.76 \times 10^{3}$ \\
$C_{m}\left(\mathrm{~J} /\left(\mathrm{kg} \cdot{ }^{\circ} \mathrm{C}\right)\right)$ & $2.85 \times 10^{3}$ & $2.85 \times 10^{3}$ & $2.93 \times 10^{3}$ & $2.93 \times 10^{3}$ \\
$K_{m}\left(\mathrm{~W} /\left(\mathrm{m} \cdot{ }^{\circ} \mathrm{C}\right)\right)$ & $1.80 \times 10^{-1}$ & $1.80 \times 10^{-1}$ & $1.80 \times 10^{-1}$ & $1.80 \times 10^{-1}$ \\
$T_{m}\left({ }^{\circ} \mathrm{C}\right)$ & 165 & 165 & 128 & 128 \\
$\lambda(\mathrm{J} / \mathrm{kg})$ & $1.33 \times 10^{5}$ & $1.33 \times 10^{5}$ & $1.09 \times 10^{5}$ & $1.09 \times 10^{5}$ \\
\hline
\end{tabular}

* PP : temp. $230^{\circ} \mathrm{C}$, weight $2.16 \mathrm{~kg}$; LLDPE : temp. $190^{\circ} \mathrm{C}$, weight $2.16 \mathrm{~kg}$

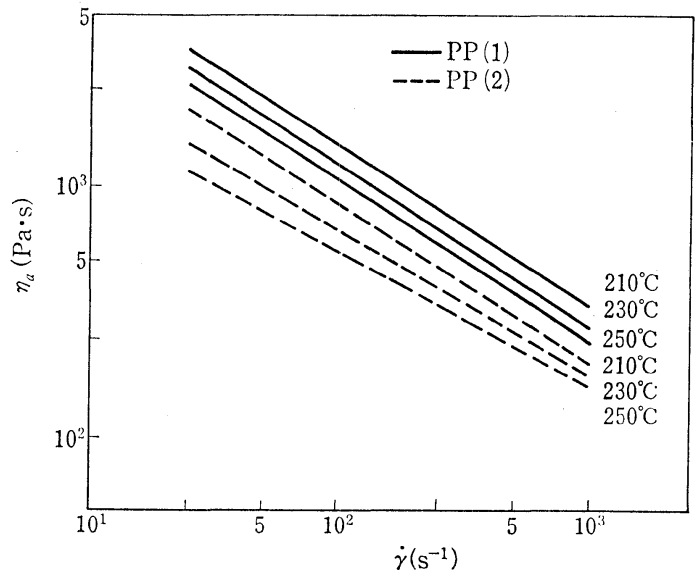

Fig. 1 Apparent melt viscosity of polypropylene

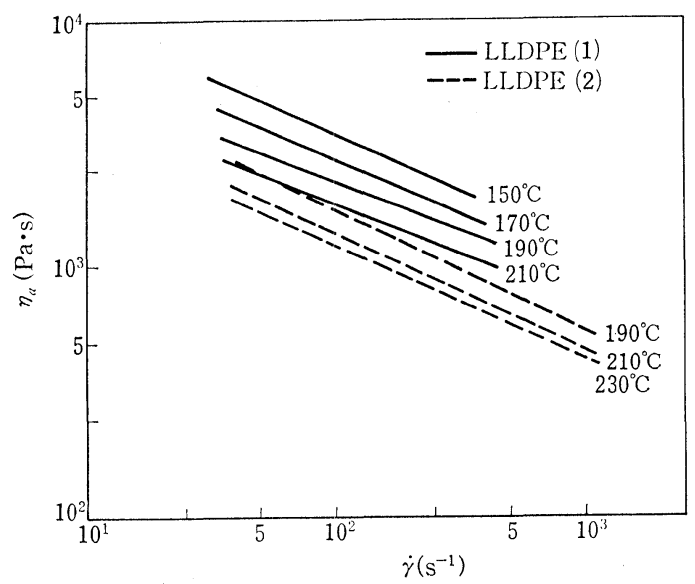

Fig. 2 Apparent melt viscosity of linear low density polyethylene

レン（LLDPE と略記）の 2 種類を用いた. 本実験に 用いた物性值を Table 1 に示す ${ }^{14)}$. をた，高化式フロ ーテスタを用いて測定した溶融粘度を Fig. 1 と Fig.
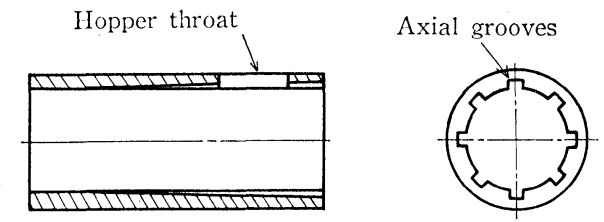

Fig. 3 Schematic view of grooved feeding section

diameter : $65 \times 10^{-3} \mathrm{~m}$, number of grooves : 8 , width : $6.5 \times 10^{-3} \mathrm{~m}$, depth : $5 \times 10^{-3} \mathrm{~m}$ tapered groove, $L / D: 5$

\section{2 に示す.}

\section{2 実験装置}

本実験に用いた装置は，供給部シリンダの内側に Fig. 3 に示すような縦方向に 8 本の縦溝を加工した溝 付きライナを設置した，強制フィード機構付き単軸ス クリュ押出機である. シリンダの加熱冷却は加熱した 油の循環で行い, 溝付きライナ部は強制水冷できる構 造としている.な拈，本実験に用いたスクリニ形状を Fig. 4 に示す.

\section{3 実験方法}

押出し条件を設定し運転を開始した後, 温度および 圧力がともに安定し定常押出しの状態になった後，ス クリュを急停止させるとともにシリンダの外側に低温 の油を循環してシリンダを急速冷却し，定常押出し時 の溶融状態を保ち，スクリュを引抜いてスクリニ溝内 から固化したサンプルを切出す. 切出したサンプルは, 溶融過程を定量化するためにスクリュフライトに直角 に切断して横断面を観察する，な拈，溶融状態を明瞭 に観察するため有機顔料を少量添加した. 固体相比は 固体相の断面積/スクリ二溝の断面積で定義した. ま た, シリンダの温度は，溝付きライナ部は全ての運転 に拈いて強水冷し，PP の押出しに拈いて溝付きライ 
(a)

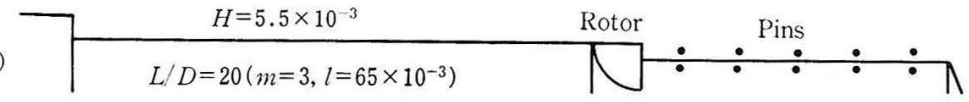

(b)

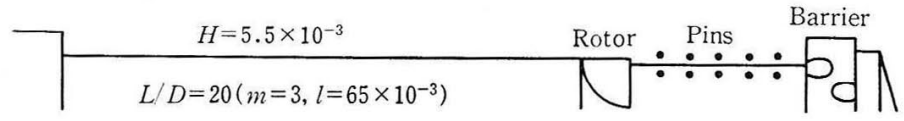

(c)

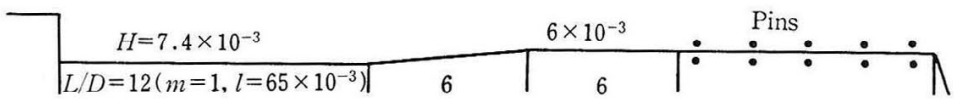

(d)

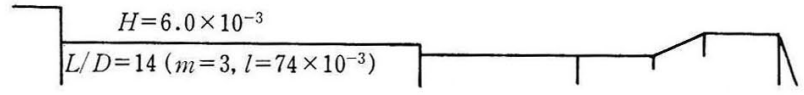

(e)

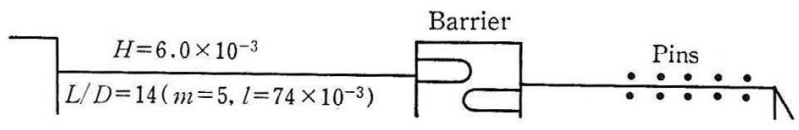

(f)

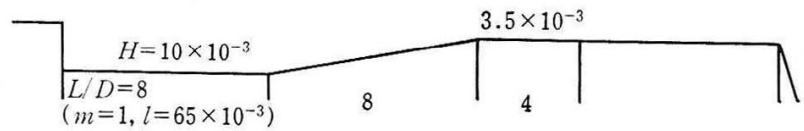

Fig. 4 Schematic view of single screw geometries

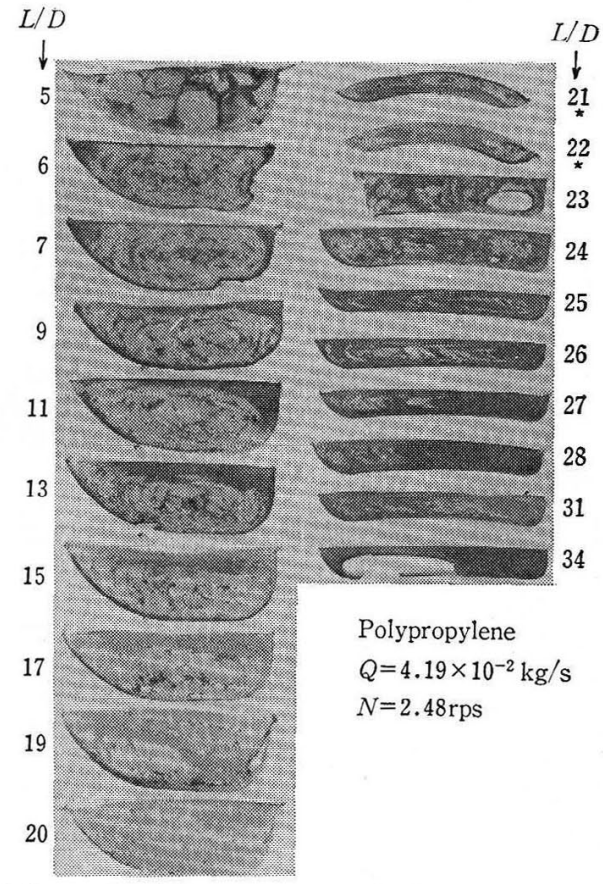

Fig. 5 Melting process of $P P(1)$ in the (a) screw channel

ナ直後のシリンダを $170^{\circ} \mathrm{C}$, それ以降は全て $230^{\circ} \mathrm{C} に$ 設定し，LLDPE の押出しにおいては全てのシリンダ を $200^{\circ} \mathrm{C}$ に設定した.

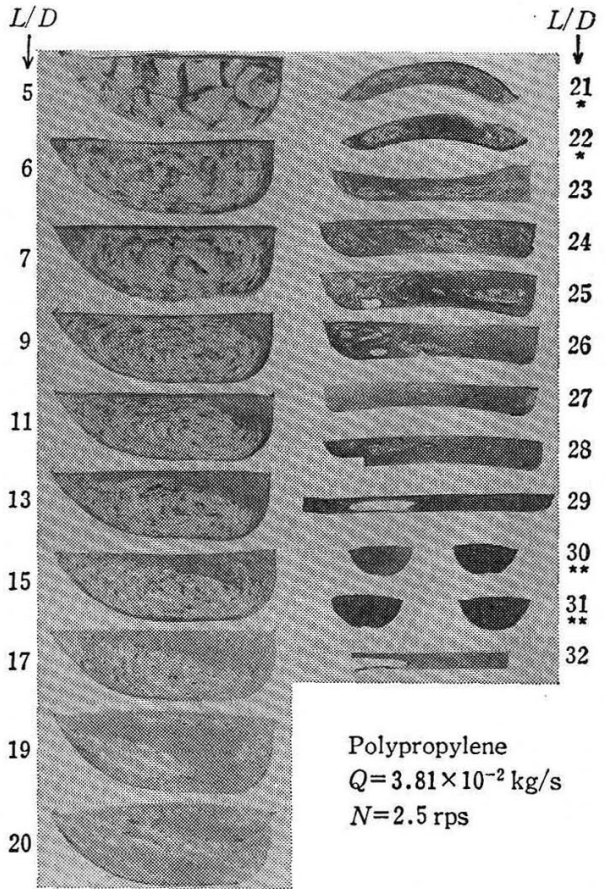

Fig. 6 Melting process of $P P(2)$ in the (b) screw channel

\section{3. 実験結果および考察}

\section{1 溶融挙動の観察}

スクリニ溝内から切出した固化サンプルを切断して 


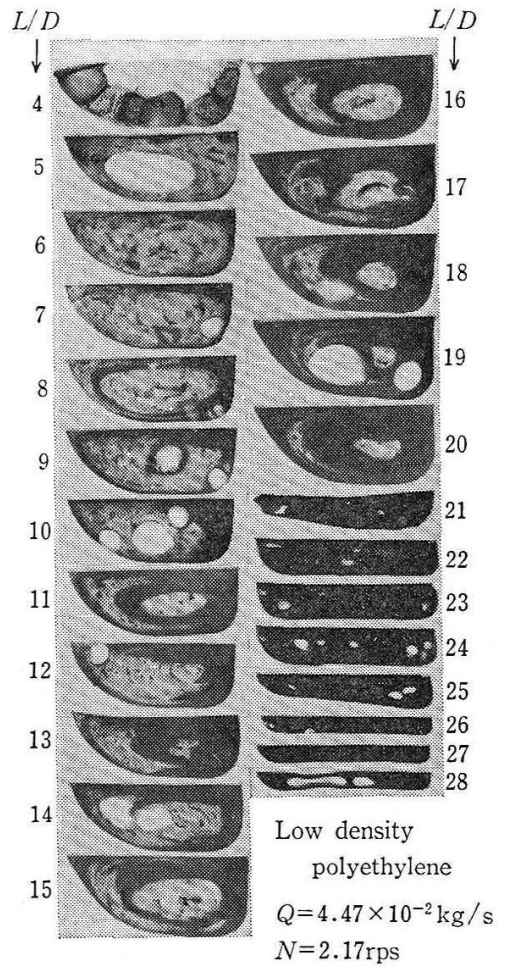

Fig. 7 Melting process of LLDPE (1) in the (d) screw channel

溶融挙動を観察した結果を, Fig. 5〜Fig.10 に示す. 各サンプルの上がシリンダ面，下がスクリニ面，右が 押付けフライト面, 左がスクリ二先端側の引付けフラ イト面に相当する. 図中の番号は，ホッパ下からスク リ二軸方向に測った位置 $(L / D)$ を示す. また，図中 白っぽい部分は，未溶融ペレットあるいはペレット同 士がその境界を消滅させて溶融しているが，また十分 混練されていない状態の未混練相を示す. 一方, 黒っ ぽい部分は, 融体が顔料と十分に混練された状態の混 練相を示す。

Fig. 5〜Fig.8 は，強制フィード機構と浅溝で多条 フライトスクリニを組合わせた場合の PP と LLDPE の溶融挙動を示す。図から明らかなように，ホッパか ら投入された固体ペレットは固体輸送部の $5 D$ 区間 で予熱，圧縮された後，溶融を開始すると同時に固体 相内で明瞭な境界を消減させて変形しながら流動して いる.すすおち，固体相内にうず状の循環流れを発生 しながら急速に溶融している. その区間はわずか数タ ーンである. 一方, 半溶融あるいは溶融した固体相と 顔料は順次層流混合されているが，十分に混練された 混練相の発達は主にシリンダ壁と固体相の界面で行わ れており，押付け側フライトの前方に融体プールを形 成しながら順次をの量を増加させている。なお，固体

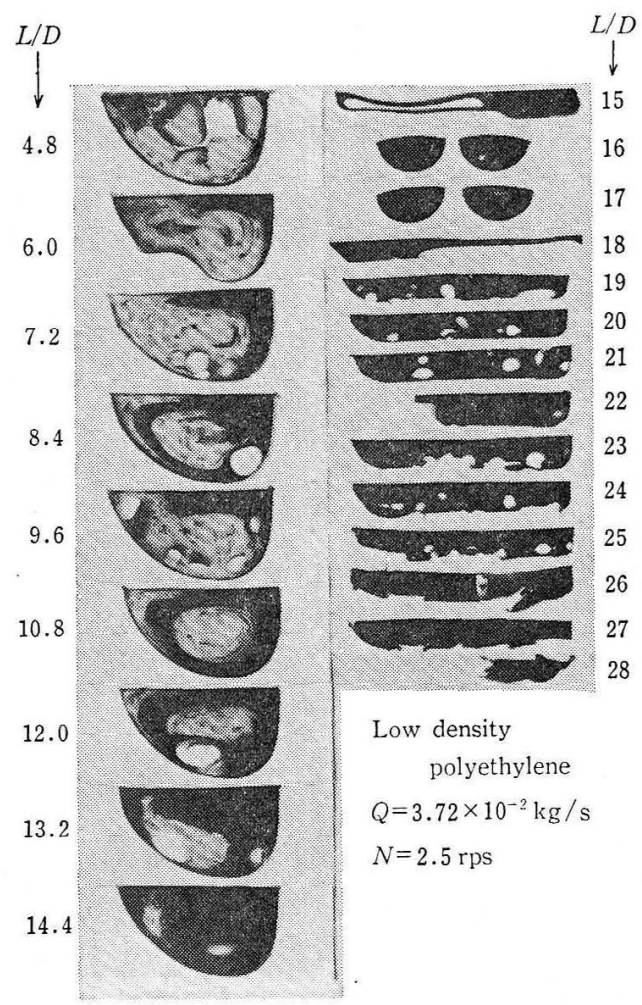

Fig. 8 Melting process of LLDPE ( 2 ) in the (e) screw channel

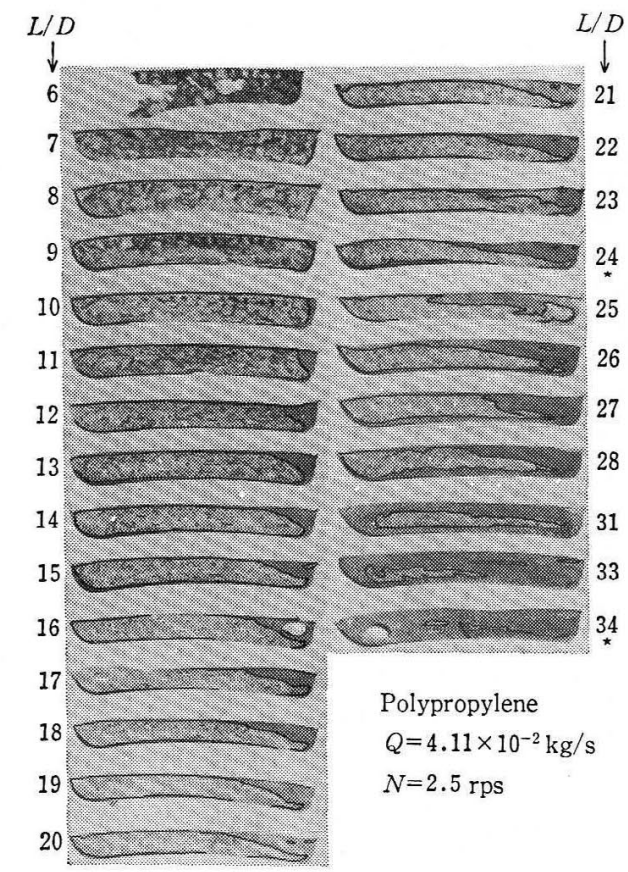

Fig. 9 Melting process of $P P(2)$ in the conventional (c) screw channel 


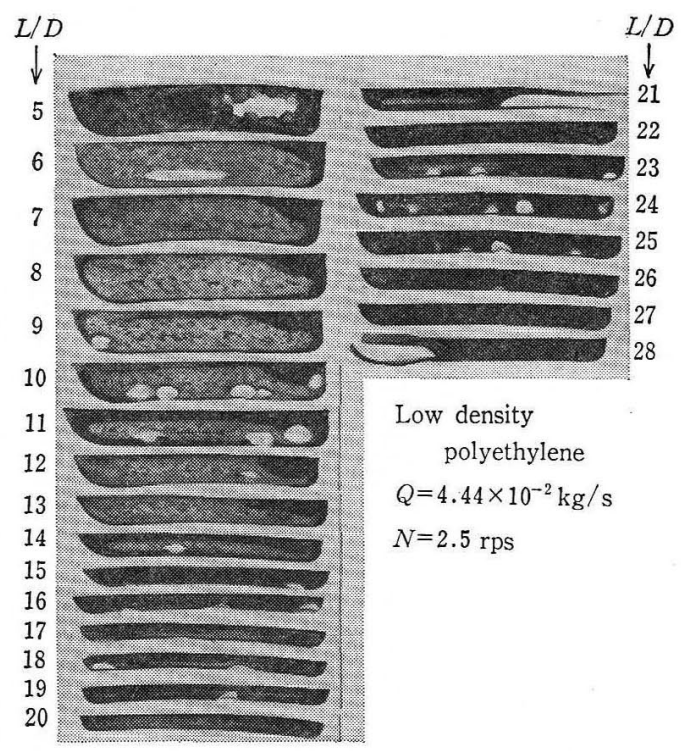

Fig. 10 Melting process of LLDPE (2) in the conventional full-flight (f) screw channel

相は溶融を開始する初期の段階では圧密状態のため, その形を崩すことなく全体的に循環流れを発生してい るが, スクリニ流路方向に進むに従って, 融体の侵入 を受けて破壊する傾向を示している. そして, 未混練 相は混練された融体中に浮遊しながら順次混練されて いる.

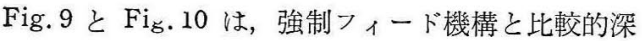
溝の 1 条フライトスクリュを組合わせた場合の PP と LLDPE の溶融挙動を示す. 図から明らかなように, ホッパから投入された固体ペレットは固体輸送部での 予熱，圧縮が緩く、シリンダ壁と固体相の界面で溶融 を開始した後でも, 固体相はその境界を明瞭に示す冷 たいペレットから形成されている.すなわら，前述の 固体相の循環流れが最後まで出現しない, そして融体 プールの発達も遅く、かつ固体相の溶融速度は遅い.

以上のごとく, 従来のスクリュでは単に強制フィー ド機構を付けて固体輸送量を高める，あるいはスクリ 二回転数を増して押出し量を比例的に増加しても, ス クリュでの溶融能力が不足して多量の未溶融物あるい は未混練相がスクリ二先端部で観察される. したがっ て，押出し物の品質が著しく損なわれて，良質限界押 出し量も非常に限定される欠点があった.

一方，これらの溶融を促進するため，強制フィード 機構と浅溝で多条フライトスクリュを組合わせて, ホ ッパから投入された固体ペレットを予熱，圧縮しなが ら高生力で圧密して, 溶融開始と同洔に毫引力と圧力 の相乗作用で固体相にうず状の循環流れを発生させれ

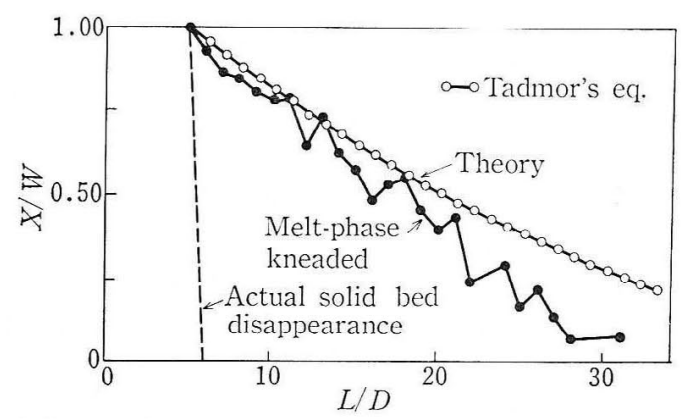

Fig. 11 Experimental and predicted solid bed profiles along (a) screw channel for PP (1)

$Q=4.19 \times 10^{-2} \mathrm{~kg} / \mathrm{s}, N=2.48 \mathrm{rps}$

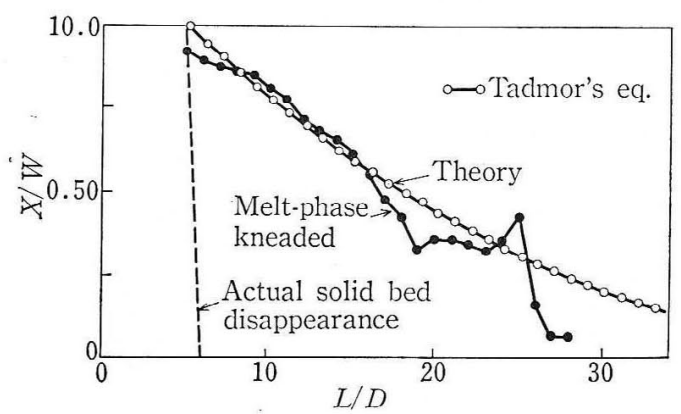

Fig. 12 Experimental and predicted solid bed profiles along (b) screw channel for PP (2)

$Q=3.81 \times 10^{-2} \mathrm{~kg} / \mathrm{s}, \quad N=2.5 \mathrm{rps}$

ば, Tadmor の溶融モデルとは異なる溶融機構が形成 されて溶融の促進が図れる.よって, 良質限界押出し 量も飛躍的に向上する.

各スクリュにおける溶融過程を定量化して, Tadmor の溶融モデルから計算した溶融速度との比較を Fig. 11〜Fig. 14 に示す. 図中縦軸は, 計算值の場合 は固体相比 $X / W$ を示すが, 実測值の破線はペレット がその境界を消滅させてうず状の循環流れを開始する 場合を示し，実線は混練㥵の発達過程を示す.なお， 計算に用いた Tadmor モデルの溶融フィルムの厚さ と溶融速度は次の通りである2,15).

$$
\begin{aligned}
& \delta=\left\{\frac{\left[2 K_{m}\left(T_{b}-T_{m}\right)+U_{1}\right] X}{V_{b x} U_{2} \rho_{m}\left[C_{s}\left(T_{m}-T_{s}\right)+\lambda\right]}\right\}^{1 / 2} \\
& \phi=\left\{\frac{V_{b x} U_{2} \rho_{m}\left[K_{m}\left(T_{b}-T_{m}\right)+U_{1} / 2\right]}{2\left[C_{s}\left(T_{m}-T_{s}\right)+\lambda\right]}\right\}^{1 / 2} \\
& \omega=\phi X^{1 / 2} \\
& \frac{X}{W}=\frac{X_{1}}{W}\left[1-\frac{\phi\left(z-z_{1}\right)}{2 \rho_{s} V_{s z} H X_{1}^{1 / 2}}\right]^{2}
\end{aligned}
$$

ここで, $U_{1}$ と $U_{2}$ はそれぞれ溶融フィルムの厚さ, 温 度およびシリンダ温度の関数である.

なお，計算機は DEC 11/44を使用した。

Fig. 11 および Fig. 12 から明らかなように, 強制フ 


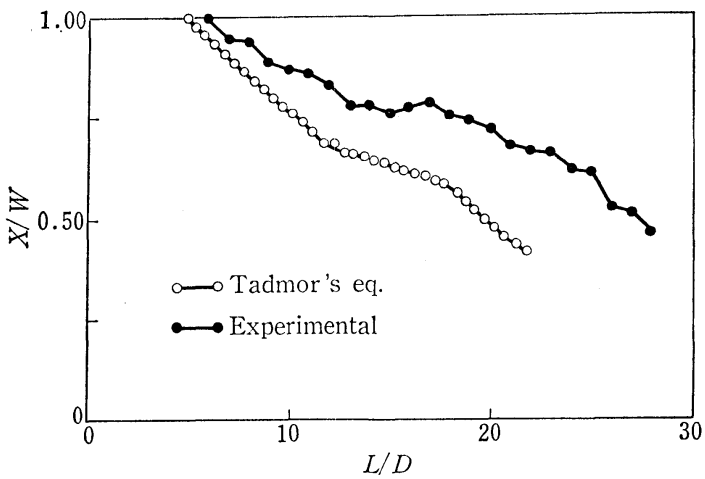

Fig. 13 Experimental and predicted solid bed profiles along (c) screw channel for PP ( 2)

$Q=4.11 \times 10^{-2} \mathrm{~kg} / \mathrm{s}, \quad N=2.5 \mathrm{rps}$

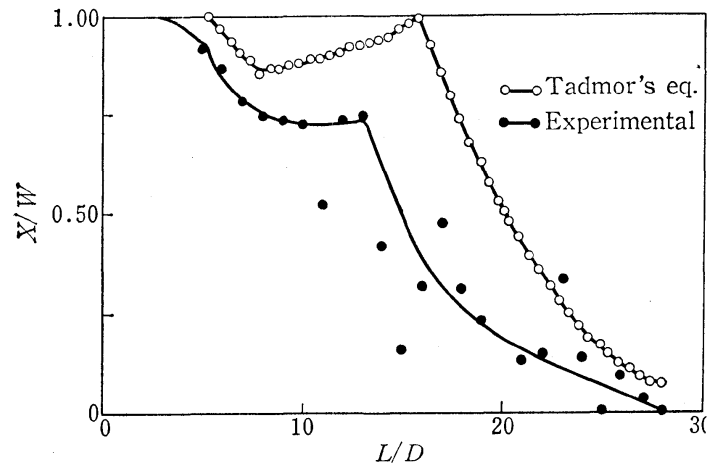

Fig. 14 Experimental and predicted solid bed profiles along ( $f$ ) screw channel for LLDPE (1)

$Q=4.44 \times 10^{-2} \mathrm{~kg} / \mathrm{s}, \quad N=2.5 \mathrm{rps}$

ィード機構と浅溝で多条フライトスクリュを組合わせ ると，図中破線で示したように，ペレットがその境界 を消減させて溶融する速度は非常に速い。これは固体 相の循環流れに起因するものである。また，混練相の 発達も, Tadmor モデルから計算した一定溝深さのフ ルフライトスクリュの溶融速度よりも速い傾向を示し ている.

一方，Fig.13 から明らかなように，低圧縮比で深 溝の 1 条フルフライトスクリュでは PP ペレットの 溶融速度は計算値より若干遅れて順次溶融している. これは, 強制フィード機構によりスクリ二回転当たり の輸送量が溝なしシリンダに比べて約 2 倍程度大きい ため, 固くて冷たいペレットの固体相がスクリュ溝内 を速く移動することに起因する.ここで Fig.13 に拉 いて計算に用いた押出し量は強制フィード機構付き押 出機に和ける実測值である。一方，Fig. 14 に示した 比較的圧縮比の高い 1 条フルフライトスクリニでは

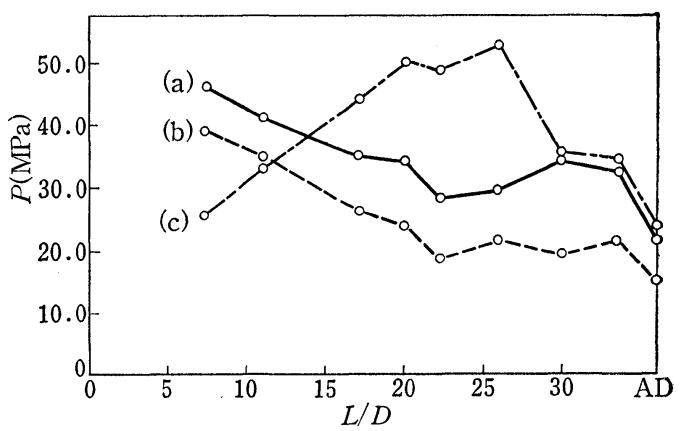

Fig. 15 Measured pressure profiles in the forced feeding single screw extruder

(a) $\mathrm{PP}(2), Q=3.81 \times 10^{-2} \mathrm{~kg} / \mathrm{s}, N=2.5 \mathrm{rps}$, (b) screw (newly developed)

(b) $\mathrm{PP}$ (1), $Q=4.19 \times 10^{-2} \mathrm{~kg} / \mathrm{s}, N=2.5 \mathrm{rps}$, (a) screw (newly developed)

(c) $\mathrm{PP}$ ( 2), $Q=4.11 \times 10^{-2} \mathrm{~kg} / \mathrm{s}, N=2.5 \mathrm{rps}$, (c) screw (conventional type)

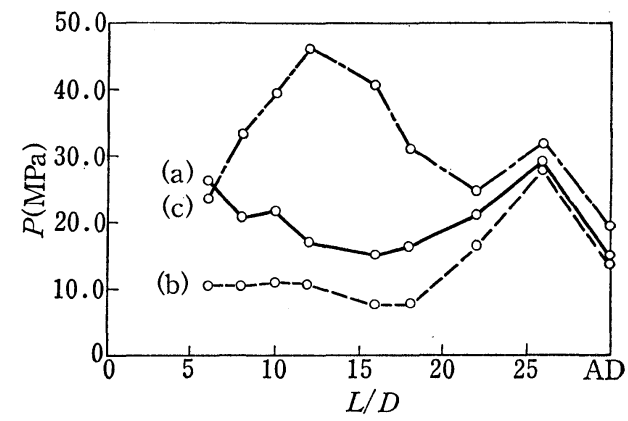

Fig. 16 Measured pressure profiles in the forced feeding single screw extruder

(a) $\operatorname{LLDPE}(1), Q=4.47 \times 10^{-2} \mathrm{~kg} / \mathrm{s}, \quad N=$ $2.2 \mathrm{rps}$, (d) screw (newly developed)

(b) $\operatorname{LLDPE}(2), Q=3.72 \times 10^{-2} \mathrm{~kg} / \mathrm{s}, \quad N=$ $2.5 \mathrm{rps}$, (e) screw (newly developed)

(c) $\operatorname{LLDPE}(2), Q=4.44 \times 10^{-2} \mathrm{~kg} / \mathrm{s}, \quad N=$ $2.5 \mathrm{rps}$, (f) screw (conventional type)

LLDPE ペレットの固体相は LLDPE の融点が低く, かつシリンダ設定温度が高いため比較的軟化しやすく て，計算値より若干速めに順次溶融している.

\section{2 圧力分布の測定}

強制フィード機構付き単軸スクリュ押出機における PP と LLDPE の圧力分布を, Fig. 15 および Fig. 16 に示す.

図から明らかなように, 強制フィード機構と浅溝で 多条フライトスクリュを組合わせると圧力勾配はスク リ二根元側が高く，そしてスクリ二先端側に向かって 漸減する傾向を示している.これは，溝付きライナ部 
で固体とシリンダとの見掛けの摩擦係数を高めてスク リニ溝内に固体ペレットを予熱, 压縮するため, 溶融 開始時の固体相が高圧力状熊にさらされることに起因 する.しかし，この状態は周体相が溶融するにつれて 次第汇緩和される，そしてスクリニ溝内の圧力は減少 していく．固体輸送部におけるペレットの予熱，压縮 過程は明らかでないが，シリンダ壁に形成された縱转 部において固体ペレットがブロックされ，内部摩擦と このブロック効果によりスクリニ溝内にペレットが予 熱，圧縮されているようである，一方，強制フィード 機構と深溝 1 条フライトスクリ二を組合わせた場合に は，圧力勾配はスクリュ根元側が低く，そしてスクリ ュ先端側に向かって漸増する傾向を示している.これ は，固体輸送部終端でのスクリ二溝内の固体ペレット の予熱，圧縮状態が弱いためである.

ここで固体輸送領域におけるペレットの圧縮に必要 な圧力を推定する. Broyer らの固体輸送式によれば, 固体相の圧力上昇は次の通りである ${ }^{16)}$.

$$
P_{2}=P_{1} \exp \left[\left(\frac{B_{1}-A_{1} K}{B_{2}+A_{2} K}\right) z\right]
$$

ここで $A_{1}, A_{2}, B_{1}$ 抢よび $B_{2}$ はそれぞれ，スクリニ 形状, 固体とスクリ二扎よびシリンダとの摩擦係数, 固体輸送量等の関数である.

溝なしのシリンダに比べて, 溝付きシリンダ部では 固体とシリンダとの見掛けの摩擦係数は大きく，固体 ペレットのブロック効果と内部摩擦とにより約 2 倍程 度に增大するようである ${ }^{17)}$. 上式に従って，本実験ス クリュでの固体輸送部終端での圧力値を試算すると, 容易に $30 \sim 40 \mathrm{MPa}$ まで指数関数的に上昇すること がわかる，試算例には次のデータを用いた．入力值は $D=65 \times 10^{-3} \mathrm{~m}, H=0.6 \times 10^{-3} \mathrm{~m}, e=0.4 \times 10^{-3} \mathrm{~m}$, $m=3, Q / N=18.767 \times 10^{-6} \mathrm{~m}^{3} / \mathrm{rev} ., l=65 \times 10^{-3} \mathrm{~m}$, $z=195 \times 10^{-3} \mathrm{~m}, f_{s}=0.23, f_{b}=0.44$ （個体之溝付き シリンダの摩擦係数)， $P_{1}=1 \mathrm{~Pa}$ である. 出力值は $P_{2}=393 \mathrm{~Pa}$ であった。 これらの高厌力により, 固体 相の密度はこの供給領域で指数関数的に増大する.

圧縮段階でのペレットの兮熱機满は明らかではない が，ペレットは融点近傍まで温度上昇するようであ る. そして溶融開始と同時に, 強い粘性牽引力と高い 圧力によって, ペレットは変形, 流動し激しい内部摩 擦発熱を伴ったうず状の循環流机を発生する。

この強制移動作用は，スクリ二溝横断面内にお汀る 等温ニュートン流孔に準じて発生する.すなおわ，一 定溝深さの矩形断面を有するスクリュ溝における $x$ 方 向の運動方程式は,

$$
\frac{\partial P}{\partial x}=\eta_{a} \frac{\partial^{2} v_{x}}{\partial y^{2}}
$$

で表される．ここで， $\eta_{a}$ は固体相の見掛けの溶融粘 度とする．境界条件を $v_{x}(0)=0, v_{x}(H)=-V_{b x}$ と して，上式を積分して整理すると次式が得られる.

$$
\frac{v_{x}}{V_{b x}}=-\frac{y}{H}+\frac{y}{H}\left(\frac{1}{2 \eta_{a}} \cdot \frac{\Delta P}{\Delta x} \cdot \frac{H^{2}}{V_{b x}}\right)\left(\frac{y}{H}-1\right)
$$

ここで溝断面内の正味の流量はゼロであるから，

$$
\int_{0}^{H} v_{x} \mathrm{~d} y=0
$$

となる.よって, 次式が得られる。

$$
\frac{\Delta P}{\Delta x}=-6 \eta_{a} \frac{V_{b x}}{H^{2}}
$$

上式はスクリ二溝横断面内の圧力勾配を示す. $\Delta P$ 值はスクリュ溝樑さ $H$ の 2 乗に反比例することを示 している、すなわわ，本実験に用いたような浅溝で多 条フライトスクリュでは圧力勾配が大きく, 溝横断面 内の循環流れがより助長される. 本実験に捺いて, ス クリ二位置が $7.3 \mathrm{~L} / D$ での圧力の振れは $3 \sim 4 \mathrm{MPa}$ であった. な技，率引力は周速成分 $V_{b x}$ である.この
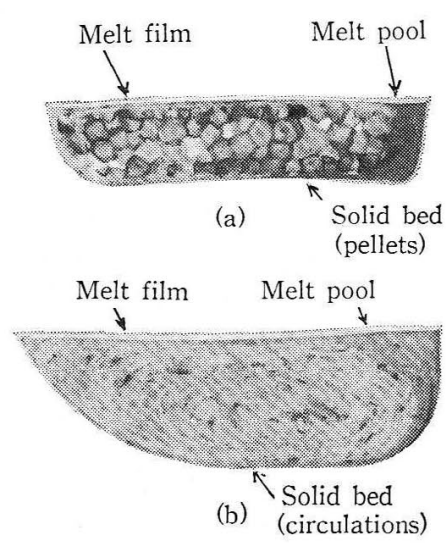

Fig. 17 Melting mechanism
(a) conventional melting
(b) improved melting newly developed

Table 2 Plasticating performance of the single screw extruder with forced feeding section $\left(D=90 \times 10^{-3} \mathrm{~m}, L /\right.$ $D=34$ )

\begin{tabular}{lcc}
\hline \multirow{2}{*}{ Material } & \multicolumn{2}{c}{ Polypropylene } \\
\cline { 2 - 3 } & $\mathrm{PP}(1)$ & $\mathrm{PP}(2)$ \\
\hline$N(\mathrm{rps})$ & 2.50 & 2.33 \\
$Q(\mathrm{~kg} / \mathrm{s})$ & 0.107 & 0.096 \\
$T\left({ }^{\circ} \mathrm{C}\right)$ & 242 & 262 \\
$E_{s p}(\mathrm{~J} / \mathrm{kg})$ & $0.893 \times 10^{6}$ & $1.076 \times 10^{6}$ \\
Sheet surface & Good & Good \\
\hline
\end{tabular}




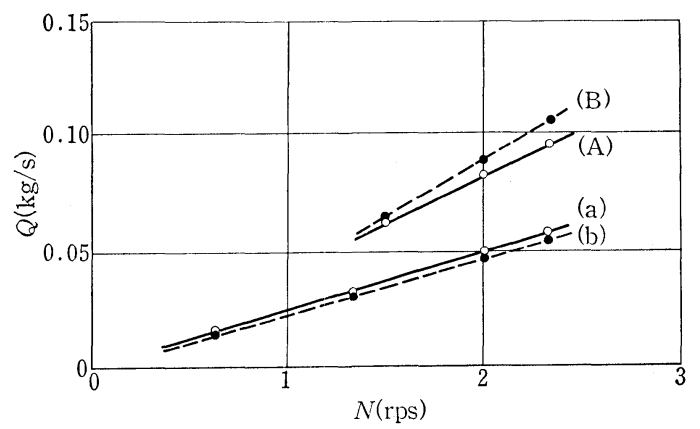

Fig. 18 Experimental output as a function of screw speed for polypropylene

(a) conventional screw with Maddock barrier, $P P(2)$

(A) MF screw with forced feeding sections, PP (2) (newly developed)

(b) conventional screw with Maddock barrier, $P P(1)$

(B) MF screw with forced feeding sections, PP (1) (newly developed)

牽引力と圧力勾配の相乗作用により，固体相の循環流 れが発生すると推定できる.

\section{3 可塑化押出 し特性}

これまでに研究開発してきた本機の特長である新規 溶融機構を Fig. 17 に示す. 図中（a）は従来の溶融 モデルを示し，（b）は本実験で 観察された 溶融の促 進を図った溶融方式である.

この特長を利用して実際に食品トレー用シート押出 し成形を試み，その可塑化押出し特性を把握した。 そ の結果の一部を Table 2 に示す. Fig. 18 と Fig. 19 に, 従来から幅広く利用されている Maddock 形スク リュと本研究の成果である強制フィード機構と浅溝で 多条フライトスクリュ（MF 形スクリュと略記）の可 塑化押出乙特性の比較例を示す.

図から明らかなように, MF 形スクリュの回転当た りの押出し量は約 $6.94 \times 10^{-4} \mathrm{~kg} / \mathrm{s}$ と大きく，したが って同一スクリュ回転数で比較すると約 $1.5 \sim 2$ 倍の 押出し量が得られた。 また，良質限界押出し量も従来 の $0.056 \mathrm{~kg} / \mathrm{s}$ 程度であったものが $0.096 \sim 0.107 \mathrm{~kg} /$ $\mathrm{s}$ まで増大した. このような押出し量の増大により， 押出乙物の温度はこれ屯で用いられているスクリュに 比べて, $\mathrm{MF}$ スクリュの方が $10 \sim 15^{\circ} \mathrm{C}$ 低い值を示し, 低温押出しが可能であることが判明した．また，比エ ネルギも $\mathrm{MF}$ スクリュの方が小さい值を示して $10 \%$ 程度の省エネルギであった．な牧，押出し物の均質性 の目安であるダイ前の圧力および温度の変動幅7は MF スクリュの方が約 $1 / 3$ に減少した. 例えば, PP

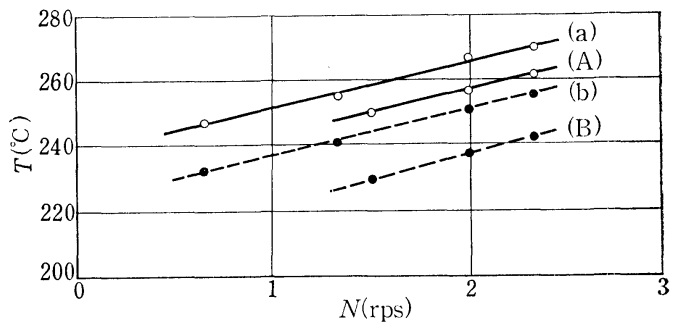

Fig. 19 Experimental melt temperature as a function of screw speed for polypropylene

(a) conventional screw with Maddock ba, rier, $P P(2)$

(A) MF screw with forced feeding sections, PP (2) (newly developed)

(b) conventional screw with Maddock barrier, $P P(1)$

(B) MF screw with forced feeding sections, PP (1) (newly developed)

(1)の押出しにおいて押出し量は $0.107 \mathrm{~kg} / \mathrm{s}$, 圧力変 動は土0.7\%，温度変動は $\pm 1.6^{\circ} \mathrm{C}$ であった。このと きのシート物性は良好であり，熱成形性（真空成形拈 よび玨空成形）も良好であった。

\section{4. むすび}

単軸スクリ二押出機において, 強制フィード機構付 きシリンダと浅溝で多条フライトスクリュを使って PP および LLDPE の溶融挙動を観察した結果, 次の 結論を得た。

（1）供給部溝付きシリンダによる固体のブロック 効果と内部摩擦により，見掛けの固体ーシリンダ摩擦 係数を高めてスクリ二回転当たりの固体輸送量を高 め，かつ固体ペレットを予熱，圧縮した状態で溶融を 開始すると，固体相内に拈いてペレットがその境界を 消滅させていくような循環流れが発生し, 溶融が著し く促進される。その結果，高いせん断応力が発生し混 練相の生成速度も著しく速くなることが明らかとなっ た.

（2）これらの溶融機構は従来の Tadmor の溶融 モデルとは異なるものである.

（3）これらの溶融機構を採用したスクリュでは, 従来のミキシングエレメントを設備したフルフライト 形スクリュに比べて約 1.5〜2 倍の押出し量と良質限 界の向上を図ることができた.

\section{5. 記 号}

$A_{1}, A_{2}:(5)$ 式に打孫数 $B_{1}, B_{2}:(5)$ 式に拈ける係数 

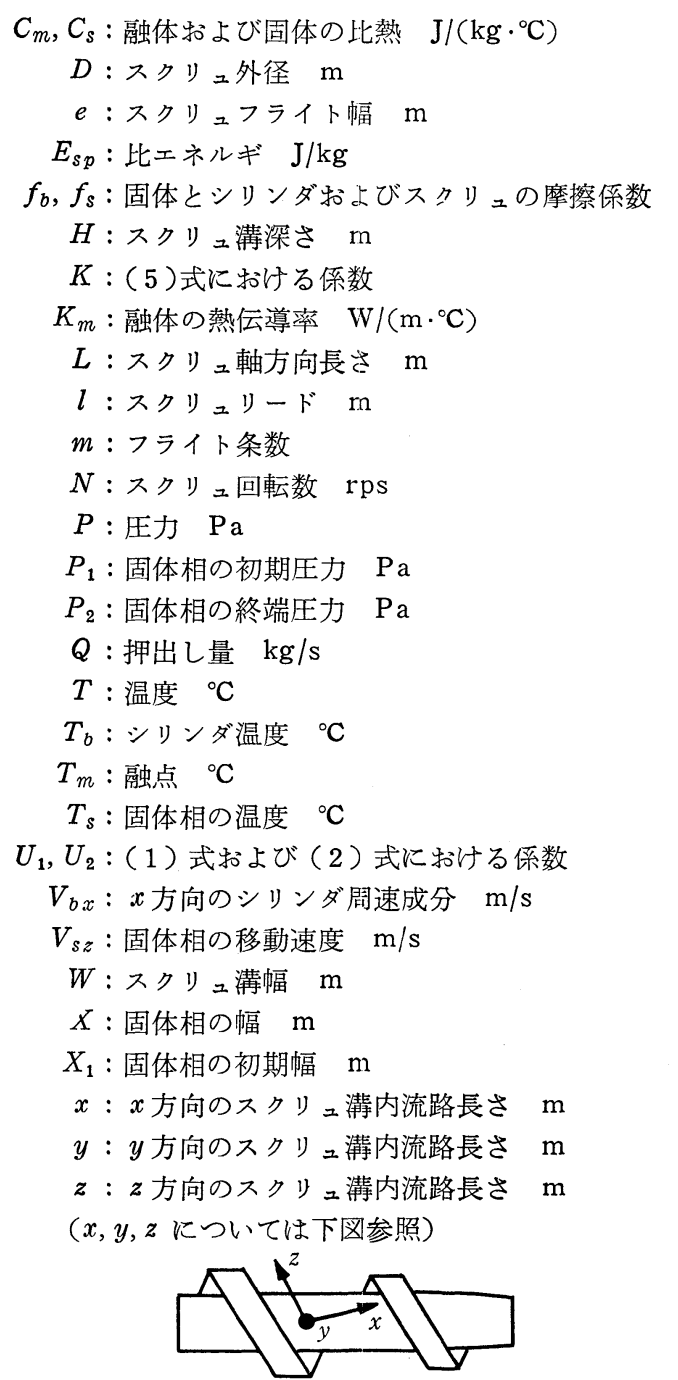

$z_{1}: z$ 方向の初期スクリ二溝内流路長さ $\mathrm{m}$ $\dot{\gamma}:$ せん断速度 $\mathrm{s}^{-1}$

$\delta:$ 溶融フィルムの厚さ $\mathrm{m}$

$\eta_{a}$ : 見掛けの溶融粘度 $\mathrm{Pa} \cdot \mathrm{s}$

$\theta:$ スリュフライトのねじれ角 $\mathrm{rad}$

$\lambda:$ 溶融潜熱 $\mathrm{J} / \mathrm{kg}$

$\rho_{m}, \rho_{s}$ : 融体および固体の密度 $\mathrm{kg} / \mathrm{m}^{3}$

$\phi:(2)$ 式における溶融速度を示唆する量.

$\omega:(3)$ 式に拈ける溶融速度 $\mathrm{kg} /(\mathrm{m} \cdot \mathrm{s})$

\section{参 考 文 献}

1) Maddock, B. H.: $S P E J$, 15, 383 (1959)

2) Tadmor, Z.: Polym. Eng. Sci., 7, 185 (1966)

3）酒井忠基, 中村和之：高分子学会年次大会, 6 (1974)

4）中村和之, 酒井忠基 : 日本化学会中国四国 -九州 支部合同大会, 11 (1974)

5）酒井忠基，溝口光明，中村和之：日本化学会中国 四国・九州支部合同大会, 10 (1980)

6) 酒井忠基, 中村和之：高分子学会年次大会, 5 (1981)

7）酒井忠基, 中村和之, 山本伸治：高分子学会高分 子討論会, 10 (1982)

8）酒井忠基：日本機械学会論文集，47，1556 (1981)

9）酒井忠基：日本機峨学会講演論文集, 817, 2(1981)

10）酒井忠基：日本製鋼所技報，41，36（1982）

11）酒井忠基：日本機械学会論文集，48，1306 (1582)

12）酒井忠基：日本機械学会論文集，49，156（1983）

13）中村和之, 田村豊治，酒井忠基 : 合成樹脂，29, 3, 25 (1983)

14) Mount, E. and Chung, C.: Polym. Eng. Sci., 18, 9, 711 (1978)

15）溝口光明 : プラスチックス, 24, 7, 60 (1973)

16) Broyer, E. and Tadmor, Z.: Polym. Eng. Sci., 12, 1 (1972)

17) Rautenbach, R. and Langecker, G. R.: Powder Tech., 12, 179 (1975) 